\title{
Replacement of maize by different levels of triticale on performances and meat yield characteristics of broiler chickens
}

\author{
Mahbub $\mathrm{ASM}^{1 *}$, Baqui $\mathrm{MA}^{2}$ and Sarker $\mathrm{NR}^{3}$ \\ ${ }^{I}$ Department of Dairy \& Poultry Science, Sylhet Agricultural University, Sylhet-3100; ${ }^{2}$ Department of Zoology, \\ Jahangirnagar University, Saver, Dhaka; ${ }^{3}$ Banglabesh Livestock Research Institute, Sava r, Dhaka, \\ Bangladesh.
}

[Received: 02 January 2011, Accepted: 28 March 2011]

\begin{abstract}
An experiment was conducted for a period of 5 weeks with 240 day-old cobb-500 broiler chicks and were allocated into six dietary treatments with isocaloric and isonitrogenous containing $2975 \mathrm{Kcal} \mathrm{ME} / \mathrm{kg} \mathrm{DM} \& 21.70 \% \mathrm{CP}$ and $3077 \mathrm{Kcal} \mathrm{ME} / \mathrm{kg} \mathrm{DM} \& 20.34 \% \mathrm{CP}$ both starter and finisher ration respectively. There were 40 chicks per treatment, each treatment had 4 replication having 10 chicks in each. The dietary treatments were $\mathrm{T}_{1}(0 \%$ triticale $+100 \%$ maize $), \mathrm{T}_{2}(20 \%$ triticale $+80 \%$ maize $), \mathrm{T}_{3}(40 \%$ triticale $+60 \%$ maize $), \mathrm{T}_{4}(60 \%$ triticale $+40 \%$ maize $), \mathrm{T}_{5}(80 \%$ triticale $+20 \%$ maize $)$ and $\mathrm{T}_{6}(100 \%$ triticale $+0 \%$ maize $)$. The broilers of all treatment groups were supplied feeds and water ad libitum throughout the experimental period. There were no significant differences ( $\mathrm{P}>0.05)$ in feed intake, final body weight, total gain, feed conversion efficiency, survivability\% but feed cost per $\mathrm{kg}$ live broiler production was differed significantly $(\mathrm{P}<0.01)$ among dietary treatments at 35 days of age. Therefore, it is clear that triticale is a good alternative cereal for broiler diet without affecting performance and it may safely replace up to $100 \%$ of maize but $40 \%$ replacement enhance production performance and edible meat yield of broiler and reducing feed cost (Tk. $2.88 / \mathrm{kg}$ ) per unit of broiler production.
\end{abstract}

Keywords: Triticale, maize replacement, production performance, meat yield characteristics

\section{INTRODUCTION}

Poultry today has emerged as the fastest growing segment of the agricultural industry. Broiler farming is an important part of commercial poultry enterprise which provides a large part of increasing demand for animal protein, cash income and creates employment opportunities. Due to the available supply of poultry feed and also its high cost, particularly energy and protein sources feed items inhabit for the formulation of least cost ration, which is the most burning issue for the development of this sector at present. Because feed cost alone accounts for $65-75 \%$ of the total cost of poultry egg \& meat production ${ }^{[1]}$. As a result poultry nutritionists have been working with various types of unconventional feed ( shrimp wastes, rumen ingesta, kitchen wastes, banana leaf meal, leucaena leaf meal and tannery wastes etc.) to reduce the poultry ration cost ${ }^{[2,3]}$. Addressing the availability of food grain for poultry as well as human in the country a cereal triticale can be substituted for other cereals in poultry diets. Triticale is the product of a cross between wheat and rye with the intention of producing a grain with the feeding characteristics of wheat and the winter hardiness, drought and disease resistance of rye ${ }^{[4]} \&$ become an important cereal that may supplant wheat or maize in some area ${ }^{[5]}$. Relatively high protein content makes triticale an attractive cereal for use in poultry diets ${ }^{[6,7]}$ Feeding triticale grain had no effects on body weight gain, feed consumption and FCR of broiler chicken even $100 \%$ replacement of wheat with triticale ${ }^{[8]}$. In another experiment revealed no differences on body weight and feed intake of broiler with a wheat-based diet but higher FCR with a diet in which when triticale was substituted for wheat ${ }^{[7]}$.

In Bangladesh there is little information about triticale grain its utilization, effects of replacement by other cereal like maize, inclusion level and economic benefits of diets and also makes popularity for abundant use as poultry ration as a cheaper feed in the country. Therefore, a study was conducted to investigate the effect of maize replacement by different level of triticale on the production performance, cost effectiveness and meat yield characteristics of broiler chicken.

\section{MATERIALS AND METHODS}

A feeding trial was conducted for a period of 5 weeks with 240 day-old Cobb-500 broiler chicks collected from a local hatchery. The initial live weights of the day old chicks were between 42-50g. The chicks were arranged in a completely randomized design with 6 dietary treatments. There were 40 chicks per treatment, each treatment had 4 replication having 10 chicks in each replicate. The dietary treatments were $\mathrm{T}_{1}(0 \%$ triticale $+100 \%$ maize), $\mathrm{T}_{2}(20 \%$ triticale $+80 \%$ maize $), \mathrm{T}_{3}(40 \%$ triticale $+60 \%$ maize $), \mathrm{T}_{4}(60 \%$ triticale $+40 \%$ maize), $\mathrm{T}_{5}(80 \%$ triticale $+20 \%$ maize $)$ and $\mathrm{T}_{6}$ (100\% triticale $+0 \%$ maize). Lighting was provided for 24 hours for the first 3 weeks and then from $1800 \mathrm{~h}$ to $0600 \mathrm{~h}$ for the rest of the days. One 
thermometer and a dry and wet bulb hygrometer were hanged in the experimental room to record temperature and relative humidity. The temperature and humidity percentages were recorded 3 times a day.

Table 1 : Feed Ingredients nutrient composition of maize-based diet used in broiler starter (0-3 weeks) ration replacing by different levels of triticale

\begin{tabular}{|c|c|c|c|c|c|c|}
\hline \multirow{2}{*}{$\begin{array}{c}\text { Feed } \\
\text { ingredients }\end{array}$} & \multicolumn{6}{|c|}{ Triticale as $\%$ of total maize grain content of the diet } \\
\hline & $T_{1}(0)$ & $\mathrm{T}_{2}(20)$ & $\mathrm{T}_{3}(40)$ & $T_{4}(60)$ & $\mathrm{T}_{5}(80)$ & $T_{6}(100)$ \\
\hline Maize & 50 & 40 & 30 & 20 & 10 & 0 \\
\hline Triticale & 0 & 10 & 20 & 30 & 40 & 50 \\
\hline Wheat & 07 & 07 & 07 & 07 & 07 & 07 \\
\hline Rice polish & 9.25 & 10.00 & 12.00 & 14.00 & 16.00 & 17.50 \\
\hline Soybean meal & 22.00 & 22.00 & 21.00 & 20.00 & 18.50 & 17.50 \\
\hline $\begin{array}{l}\text { *Protein } \\
\text { Concentrate }\end{array}$ & 6.50 & 5.50 & 4.50 & 3.50 & 3.00 & 2.50 \\
\hline $\begin{array}{l}\text { Meat \& Bone } \\
\text { meal }\end{array}$ & 2.50 & 2.50 & 2.50 & 2.50 & 2.50 & 2.50 \\
\hline Soybean oil & 1.0 & 1.0 & 1.0 & 1.0 & 1.0 & 1.0 \\
\hline DCP & 1.0 & 1.25 & 1.25 & 1.25 & 1.25 & 1.25 \\
\hline Lysine & 0.1 & 0.1 & 0.1 & 0.1 & 0.1 & 0.1 \\
\hline Methionine & 0.1 & 0.1 & 0.1 & 0.1 & 0.1 & 0.1 \\
\hline $\begin{array}{l}\text { Vitamin } \\
\text { mineral Premix }\end{array}$ & 0.25 & 0.25 & 0.25 & 0.25 & 0.25 & 0.25 \\
\hline Commol Salt & 0.3 & 0.3 & 0.3 & 0.3 & 0.3 & 0.3 \\
\hline Total & 100 & 100 & 100 & 100 & 100 & 100 \\
\hline
\end{tabular}

$\begin{array}{lcccccc}\begin{array}{l}\text { Calculated composition: } \\ \text { Crude protein }\end{array} & 21.44 & 21.56 & 21.61 & 21.66 & 21.79 & 22.08 \\ & & & & & & \\ \text { ME, Kcal/kg } & 3016.40 & 2980.60 & 2972.50 & 2964.40 & 2961.40 & 2953.95 \\ & & & & & & \\ \text { Crude fiber } & 4.62 & 4.58 & 4.46 & 4.36 & 4.31 & 4.49 \\ \text { Crude fat } & 5.46 & 5.19 & 5.07 & 4.94 & 4.86 & 4.73 \\ \text { Crude ash } & 5.06 & 4.94 & 4.89 & 4.84 & 4.86 & 4.88 \\ \text { Lysine } & 1.16 & 1.13 & 1.15 & 1.13 & 1.14 & 1.15 \\ \text { Methionine } & 0.45 & 0.45 & 0.45 & 0.44 & 0.45 & 0.44 \\ & 0.34 & 0.33 & 0.33 & 0.32 & 0.31 & 0.31 \\ \text { Methionine+Cystine } & 0.34 & & & & & \\ \text { Tryptophan } & 0.26 & 0.26 & 0.25 & 0.25 & 0.25 & 0.25 \\ \text { Calcium } & 0.96 & 1.01 & 0.96 & 0.90 & 0.87 & 0.85 \\ \begin{array}{l}\text { Available } \\ \text { Phosphorus }\end{array} & 0.97 & 0.96 & 0.95 & 0.94 & 0.93 & 0.92\end{array}$

Composition: CP $60 \%$ ME $3230 \mathrm{kcal} / \mathrm{kg}$, crude fat $10-12 \%$, crude fiber $4 \%$, ash $21 \%$, moisture $7 \%$, calcium $5.8 \%$, phosphorus $2.4 \%$, arginine $4.05 \%$, isoleucine $1.77 \%$, lysine $3.20 \%$, methionine+cystine $0.91 \%$, phenylalanine $2.35 \%$, threonine $2.21 \%$, valine $2.61 \%$.

One feeder and one round drinker were provided in each pen for 10 birds. All mash dry diets were supplied in different feeders for each replication under each treatment to all birds ad-libitum, three times a day throughout the experimental period. Water also provided once daily in the morning. The birds were vaccinated against Newcastle ( $1^{\text {st }}$ day and $21^{\text {st }}$ day) and Gumboro disease $\left(7^{\text {th }}\right.$ day and $14^{\text {th }}$ day). Table 2: Feed Ingredients and nutrient composition of maize-based diet used in broiler finisher (3-5 weeks) ration replacing by different levels of triticale

\begin{tabular}{|c|c|c|c|c|c|c|}
\hline \multirow[t]{2}{*}{ Feed ingredients } & \multicolumn{6}{|c|}{ Triticale as \% of total maize grain content of the diet } \\
\hline & $\mathrm{T}_{1}(0)$ & $\mathrm{T}_{2}(20)$ & $\mathrm{T}_{3}(40)$ & $\mathrm{T}_{4}(60)$ & $\mathrm{T}_{5}(80)$ & $T_{6}(100)$ \\
\hline Maize & 50 & 40 & 30 & 20 & 10 & 0 \\
\hline Triticale & 0 & 10 & 20 & 30 & 40 & 50 \\
\hline Wheat & 7.0 & 7.0 & 7.0 & 7.0 & 7.0 & 7.0 \\
\hline Rice polish & 11.00 & 12.75 & 14.75 & 16.75 & 18.25 & 19.50 \\
\hline Soybean meal & 19.00 & 18.00 & 17.00 & 16.00 & 15.00 & 14.25 \\
\hline *Protein Concentrate & 6.50 & 5.50 & 4.50 & 3.50 & 3.00 & 2.50 \\
\hline Meat \& Bone meal & 2.50 & 2.50 & 2.50 & 2.50 & 2.50 & 2.50 \\
\hline Soybean oil & 2.25 & 2.25 & 2.25 & 2.25 & 2.25 & 2.25 \\
\hline DCP & 1.0 & 1.25 & 1.25 & 1.25 & 1.25 & 1.25 \\
\hline Lysine & 0.1 & 0.1 & 0.1 & 0.1 & 0.1 & 0.1 \\
\hline Methionine & 0.1 & 0.1 & 0.1 & 0.1 & 0.1 & 0.1 \\
\hline $\begin{array}{l}\text { Vitamin mineral } \\
\text { Premix }\end{array}$ & 0.25 & 0.25 & 0.25 & 0.25 & 0.25 & 0.25 \\
\hline Commol Salt & 0.3 & 0.3 & 0.3 & 0.3 & 0.3 & 0.3 \\
\hline Total & 100 & 100 & 100 & 100 & 100 & 100 \\
\hline
\end{tabular}

Calculated composition:

\begin{tabular}{|c|c|c|c|c|c|c|}
\hline \\
\hline Crude protein & 20.11 & 20.13 & 20.18 & 20.23 & 20.52 & 20.89 \\
\hline $\mathrm{ME}, \mathrm{Kcal} / \mathrm{kg}$ & 3103.17 & 3089.32 & 3081.22 & 3073.12 & 3065.67 & 3056.0 \\
\hline Crude fiber & 3.44 & 3.61 & 3.80 & 3.98 & 4.16 & 4.35 \\
\hline Crude fat & 6.86 & 6.70 & 6.58 & 6.45 & 6.32 & 6.15 \\
\hline Crude ash & $4 . .99$ & 4.92 & 4.83 & 4.82 & 4.83 & 4.84 \\
\hline Lysine & 1.12 & 1.10 & 1.07 & 1.05 & 1.03 & 1.03 \\
\hline Methionine & 0.44 & 0.43 & 0.44 & 0.42 & 0.42 & 0.42 \\
\hline Methionine+Cystine & 0.32 & 0.31 & 0.30 & 0.29 & 0.29 & 0.29 \\
\hline Tryptophan & 0.23 & 0.23 & 0.23 & 0.22 & 0.22 & 0.22 \\
\hline Calcium & 1.00 & 0.98 & 0.95 & 0.89 & 0.86 & .083 \\
\hline $\begin{array}{l}\text { Available } \\
\text { Phosphorus }\end{array}$ & 0.97 & 0.95 & 0.94 & 092 & 0.90 & 0.89 \\
\hline
\end{tabular}

Feeding trial was performed for a period of 35 days. Feed conversion ratio for a particular period was calculated dividing the total feed consumed by the cumulative body weight attained at that period. Management like litter, feeding system and temperature were similar for all treatments. At the end of 5 weeks, 2 broiler from each replication i.e, 8 birds from each treatment was randomly selected considering around same body weight and slaughtered to analyze the morphological and edible meat yield characteristics. Birds were slaughtered following halal method ${ }^{[9]}$ by serving the jugular vein and allowed to bleed completely. 
For morphological characteristics such as length of neck, thigh, drumstick and wing were recorded by a measuring scale.

Collected and Calculated data were analyzed for analysis of variance using MSTAT-C Computer package program in according to the principles of Completely Randomized Design (CRD). Least Significance Difference (LSD) was done to compare variations between treatments where adjudged by Duncan's New Multiple Range Test.

\section{RESULTS AND DISCUSSION}

\section{Weight gain:}

The results on live weight of broilers fed different levels of triticale based diets are shown in Table-3. The live weight did not differ significantly $(\mathrm{P}<0.01)$. However, the highest live weight and weight gain of broilers were found when $40 \%$ maize was replaced with triticale (T4). The present findings of live weight of broilers are agreed with the investigation of other scientists ${ }^{[8,13]}$. Whole triticale in the pelleted food produced identical body weight responses to when ground triticale was incorporated in the food ${ }^{[14]}$. However, broiler feeding untreated triticale grain up to $50 \%$ instead of corn had no effect on weight gain ${ }^{[15]}$. However, diet containing upto $30 \%$ triticale obtained higher weight gain but differences were similar ${ }^{[17]}$. Triticale could substitute maize up to the level of $50 \%$ did not affect weight gain in the diets of growing chicks ${ }^{[18]}$. When $60 \%$ wheat was replaced with triticale grain in cobb-500 broiler ration at 35 days of age lead significantly higher $(\mathrm{P}<0.01)$ final weight gain ${ }^{[19]}$. Higher weight gain observed in broilers fed maize-triticale diets than fed a diet with triticale as the only cereal grain ${ }^{[20]}$.

The higher concentration of triticale or different levels of triticale replaced with maize or wheat-based diet or other cereal sources in broiler ration decreased body weight as reported by other scientists which are agreed the present study.

\section{Feed conversion ratio:}

Feed conversion ratio of broilers received different level of triticale in maize-based dietary treatments was not significantly different at 35 days that is similar with another studies used a corn-soy basal diet with different inclusion of triticale were given to male Ross broiler chicks and found no significant differences in FCR at 42 days ${ }^{[16,28,21]}$. It was reported that significantly no differences of FCR on meat type chickens at 28 days given maize and soybean meal based diet replacing maize with 35 , 69.55 or $100 \%$ by triticale grain ${ }^{[25]}$.

\section{Feed consumption:}

Feed consumption of broilers among different levels of triticale-based dietary groups were not statistically $(\mathrm{P}<0.01)$ different at 35 days that is agreed with another research ${ }^{[7,8]}$. It was also reported that broiler feeding untreated triticale grain up to $100 \%$ replacement with corn had no effect on feed consumption ${ }^{[15]}$. In another experiment found no significant difference in feed consumption when corn was replaced with different levels of triticale grain for Ross broiler diet at 42 days ${ }^{[16]}$. It was concluded from an experiment that feed intake was not significantly different among the groups when diet included triticale $30 \%$, maize $20 \%$ and wheat $15 \%$ in the diet of Lohmann broilers ${ }^{[26]}$.

Table 3: Production performances of broiler chicken fed on maize-based diet replacing by different levels of triticale

\begin{tabular}{|c|c|c|c|c|c|c|c|}
\hline \multirow{2}{*}{ Varaibles } & \multicolumn{6}{|c|}{ A1 $15 \% 0$} & \multirow{2}{*}{$\begin{array}{l}\text { LSDDSED } \\
\text { sand devel } \\
\text { significicanc }\end{array}$} \\
\hline & $\mathrm{T} 1(0)$ & $T 22(20)$ & $\mathrm{T} 33(4)$ & $T 4(8)$ & $\mathrm{TS}(80)$ & $T \&(100)$ & \\
\hline $\begin{array}{l}\text { Initial body } \\
\text { weieght(g/fiti } \\
\text { rdd) }\end{array}$ & 45.3622 .04 & 45.4012 .68 & 45.49+1.41 & $45.51 \pm 2.64$ & $45.41 \pm 2.39$ & $45.42 \pm 2.00$ & $1.118 \mathrm{NS}$ \\
\hline $\begin{array}{l}\text { Final body } \\
\text { weight(g/bi } \\
\text { rd) }\end{array}$ & $\begin{array}{l}1472.96+7.7 \\
42\end{array}$ & $\begin{array}{c}1483.88 \pm 1 \\
1.95\end{array}$ & $\begin{array}{l}1498.5441 \\
1.25\end{array}$ & $\frac{1478.21 \pm 2}{6.54}$ & $\begin{array}{l}1470.78711 \\
4.98\end{array}$ & $\begin{array}{c}1466.42+22 . \\
81\end{array}$ & $8.595 \mathrm{NS}$ \\
\hline $\begin{array}{c}\text { Body } \\
\text { weight } \\
\text { gaing(ghbird }\end{array}$ & $\begin{array}{l}1427.7555 .5 . \\
86\end{array}$ & $\begin{array}{l}144.1 .54 \pm 1 \\
5.15\end{array}$ & $\begin{array}{l}1453.05 \pm 1 \\
1.17\end{array}$ & $\frac{1432.64 \pm 2}{6.16}$ & $\frac{1425.37 \pm 1}{7.34}$ & $\begin{array}{l}1421.00 \pm 23 . \\
85\end{array}$ & $8.996 \mathrm{NS}$ \\
\hline $\begin{array}{c}\text { Feed } \\
\text { consumptio } \\
\text { n(g/hirid) }\end{array}$ & $\begin{array}{c}2614.25 \pm 1 \\
5.17\end{array}$ & $\begin{array}{c}2611.6941 \\
0.48\end{array}$ & $\begin{array}{c}2666.941 \\
2.23\end{array}$ & $\begin{array}{r}2610.19 \pm 7.7 \\
20\end{array}$ & $\begin{array}{l}2619.2559 . \\
42\end{array}$ & $\frac{2626.06+8.0}{6}$ & $5.381 \mathrm{NS}$ \\
\hline $\begin{array}{l}\begin{array}{l}\text { FCR(g } \\
\text { feeddg } \\
\text { gain) }\end{array}\end{array}$ & $1.83 \pm 0.01$ & $1.81 \pm 0.02$ & $1.79 \pm 0.01$ & $1.82 \pm 0.03$ & $1.83 \pm 0.03$ & $1.85 \pm 0.04$ & $0.015 \mathrm{NS}$ \\
\hline $\begin{array}{c}\text { Survivabili } \\
\text { ty } \% \%\end{array}$ & $97.50 \pm 0.82$ & $97.50 \pm 0.82$ & 97.5000 .82 & $95.00 \pm 0.82$ & $97.50 \pm 0.82$ & $95.00 \pm 0.82$ & $4.876 \mathrm{NS}$ \\
\hline $\begin{array}{c}\text { Feed } \\
\text { cost(Tk/kg } \\
\text { broiler) in } \\
\text { 20007-2008 }\end{array}$ & $\frac{40.99 \div 0.4}{1}$ & $\begin{array}{c}39.60^{\mathrm{h}} \pm 0.0 . \\
41\end{array}$ & $\begin{array}{l}38.11^{b^{1}+4}+0 . \\
81\end{array}$ & $37.22^{x} \pm 0.8$ & $\frac{36.89 \div 1.2}{2}$ & $36.24^{4} \pm 0.41$ & $4.422^{* *}$ \\
\hline
\end{tabular}

\section{Survivability:}

The survivability percent of Cobb-500 broilers received different level of triticale in maize-based diet did not differ significantly at 35 days. The highest survivability of birds were recorded on dietary group T1, T2, T3 \& T5 whereas lowest on group T4 \& T6 respectively. The lower survibility of birds might be happened due to heat stress during experimental period. The present observation of survivability about triticale feeding in broiler diets is consistent with the previous findings as reported in various studies ${ }^{[29,17,16]}$. Moreover, many researcher reported that there were no differences on survivability about triticale feeding even diets consists of $100 \%$ triticale in the broiler or layer ration $[1,8,19]$.

\section{Feed cost:}

Feed cost per unit of broiler production in terms of profitability was highest due to reduced feed cost (2.88 Tk. $/ \mathrm{kg})$ per unit of production when broilers fed a diet in which $40 \%$ maize was replaced with triticale grain (T3). The present study of reducing feed cost per unit of broiler production is supported with the previous findings of other researcher ${ }^{117,19,31]}$ They also noted that cost reduction from using triticale ranged from 1.3 to $2.3 \%$ for broiler rations 
and from 1.87 to $3.54 \%$ for layer rations when triticale was priced equal to corn.

\section{The Morphological characteristics:}

The morphological characteristics (Table-4) were almost similar in all the treatments and the differences were non-significant. It reveals that triticale-based diets have no negative effect on body characteristics of broiler. The present finding of this study is agreed with another investigation that showed no differences of body characteristics of cobb-500 broilers fed different levels of triticale in wheat-based diet at 35 days ${ }^{[19]}$. However, the length of wing and shank were not affected among dietary treatments ${ }^{[3,8]}$ which are agreed in the present study.

Table 4: Effect of feeding different levels of triticale on the body characteristics of broiler chicken in maize-based diets.

\begin{tabular}{|c|c|c|c|c|c|c|c|}
\hline \multirow[t]{2}{*}{$\begin{array}{l}\begin{array}{l}\text { Variables } \\
\text { (cm) }\end{array} \\
\text { a }\end{array}$} & \multicolumn{6}{|c|}{ Treatment groups } & \multirow{2}{*}{$\begin{array}{l}\text { SED(LSD) } \\
\& \text { level of } \\
\text { significance }\end{array}$} \\
\hline & $\mathrm{T}_{\mathrm{i}}$ & $\mathrm{T}_{2}$ & $\mathrm{~T}_{3}$ & $\mathrm{~T}_{4}$ & $\mathrm{~T}_{\mathrm{s}}$ & $\mathrm{T}_{6}$ & \\
\hline Neck & $11.08 \pm 0.1$ & ${ }_{21}^{11.11 \pm 0}$ & $\begin{array}{l}11.06 \pm 0.2 \\
4\end{array}$ & $\begin{array}{l}10.73 \pm 0 \\
.17\end{array}$ & $\frac{10.90 \pm 0}{.23}$ & $\begin{array}{l}10.93 \pm 0 \\
.29\end{array}$ & $(0.114) \mathrm{NS}$ \\
\hline Thigh & $5.46 \pm 0.22$ & $\begin{array}{c}5.52 \pm 0 . \\
11\end{array}$ & $5.45 \pm 0.14$ & $\begin{array}{c}5.44+0 . \\
18\end{array}$ & $\begin{array}{c}5.39 \pm 0 . \\
16\end{array}$ & $\begin{array}{c}5.49 \pm 0 . \\
12\end{array}$ & $(0.080)$ NS \\
\hline Drumstick & $9.53 \pm 0.17$ & $\begin{array}{c}\frac{9.56+0 .}{15} \\
.\end{array}$ & $9.65 \pm 0.10$ & $\begin{array}{l}9.49 \pm 0 . \\
14\end{array}$ & $\begin{array}{c}9.44 \pm 0 . \\
14\end{array}$ & $\begin{array}{c}9.56 \pm 0 . \\
21\end{array}$ & $(0.077) \mathrm{NS}$ \\
\hline Wing & $\underset{17.88 \pm 0.1}{1}$ & $\begin{array}{c}17.92 \pm 0 \\
.16\end{array}$ & $\frac{1794 \pm 0.1}{3}$ & $\begin{array}{c}17.77 \pm 0 \\
.13\end{array}$ & $\begin{array}{c}17.80 \pm 0 \\
.10\end{array}$ & $\frac{17.99 \pm 0}{.11}$ & $(0.063) \mathrm{NS}$ \\
\hline Shank & $5.48 \pm 0.13$ & $\begin{array}{c}5.36 \pm 0 . \\
05\end{array}$ & $5.39 \pm 0.11$ & $\begin{array}{c}5.28 \pm 0 . \\
10\end{array}$ & $\begin{array}{c}5.31 \pm 0 . \\
11\end{array}$ & $\begin{array}{c}5.35 \pm 0 . \\
09\end{array}$ & $(0.05) \mathrm{NS}$ \\
\hline
\end{tabular}

On the other hand, it was observed statistically different in the length of neck $(\mathrm{P}<0.001)$, thigh $(\mathrm{P}<0.05)$ and drumstick $(\mathrm{P}<0.05)$ among triticalebased diets when replacing different levels of triticale in wheat-based diets on carcass characteristics of Starbro broiler at 35 days of age ${ }^{[8]}$ whereas, the length of thigh and drumstick were affected on different dietary treatments while observation of carcass characteristics of cockrels due to strains and age ${ }^{[32]}$ were disagreed with the present study.

\section{Meat yield characteristics:}

The highest dressing yield percent was obtained by the birds of dietary group in which $40 \%$ maize was replaced with triticale grain. It indicates that dressing weight percent increased with the increasing level of triticale up to $40 \%$ and $100 \%$ alone in the diet. The breast meat yield was significantly $(\mathrm{P}<0.01)$ increased with higher level of triticale but had no effect up to $40 \%$ replacement of triticale in maize based diet of cobb-500 broiler at 35 days. The causes of increasing dressed weight might be due to the fact that triticale had a positive effect on Cobb500 broiler with increasing the thigh, drumstick and breast meat because correlation between live weight and dressing weight $(\mathrm{r}=0.76)$, thigh $(\mathrm{r}=0.71)$, drumstick $(\mathrm{r}=0.74)$ and breast meat $(\mathrm{r}=0.61)$ all were positive. It is also evident that sole triticale-based diet obtained better dressing yield percent than sole wheat based diet.

Similarly report showed that there were no effects on carcass weight, uniformity of carcass (measured as CV \%) \& percentage of grade-A carcass fed triticale or wheat-based diet at 42 days ${ }^{[7]}$. On the other hand, dressing yield percent of Starbro broiler chickens were significantly $(\mathrm{P}<0.05)$ differences among different level of triticale in wheat-based diets at 35 days ${ }^{[8]}$ and also different of dressed weight $\%$ of cockrels among various diets due to strains and age

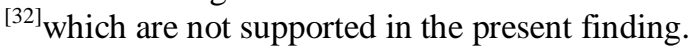

Table 5: Effect of feeding different level of triticale on the edible meat yield characteristics of broiler chicken in maize-based diets

\begin{tabular}{|c|c|c|c|c|c|c|c|}
\hline \multirow{2}{*}{$\begin{array}{c}\text { Variabl } \\
\text { es } \%\end{array}$} & \multicolumn{6}{|c|}{ Treatment } & \multirow{2}{*}{$\begin{array}{c}\text { SED(LS } \\
\text { D) \& } \\
\text { level of } \\
\text { significan } \\
\text { ce }\end{array}$} \\
\hline & $\mathrm{T}_{\mathrm{t}}$ & $\mathrm{T}_{2}$ & $\mathrm{~T}_{3}$ & $\mathrm{~T}_{4}$ & $\mathrm{~T}_{5}$ & $\mathrm{~T}_{6}$ & \\
\hline $\begin{array}{l}\text { Dressin } \\
\mathrm{g} \text { yield }\end{array}$ & $\underset{9}{70.06 \pm 1.7}$ & $\frac{70.63 \pm 2.0}{1}$ & $\begin{array}{c}71.36 \pm 1.1 \\
0\end{array}$ & $\underset{4}{69.57 \pm 1.7}$ & $\underset{5}{69.29 \pm 1.3}$ & $\underset{3}{70.28 \pm 1.2}$ & $0.786 \mathrm{NS}$ \\
\hline Thigh & $\begin{array}{c}11.54 \pm 0.1 \\
7\end{array}$ & $\begin{array}{c}11.61 \pm 0.1 \\
8\end{array}$ & $\begin{array}{c}11.75 \pm 0.3 \\
7\end{array}$ & $\begin{array}{c}11.46 \pm 0.2 \\
9\end{array}$ & $\begin{array}{c}11.39 \pm 0.2 \\
0\end{array}$ & $\begin{array}{c}11.60 \pm 0.1 \\
9\end{array}$ & $0.122 \mathrm{NS}$ \\
\hline $\begin{array}{c}\text { Drumst } \\
\text { ick }\end{array}$ & $8.55 \pm 0.16$ & $8.74 \pm 0.21$ & $8.77 \pm 0.27$ & $8.57 \pm 0.20$ & $8.50 \pm 0.12$ & $8.66 \pm 0.34$ & $0.114 \mathrm{NS}$ \\
\hline $\begin{array}{c}\text { Breast } \\
\text { meat }\end{array}$ & $18.6^{7^{\star}} \pm 0$ & $\begin{array}{c}18.98^{8} \pm 0 \\
28\end{array}$ & $\begin{array}{c}19.03^{2} \pm 0 . \\
25\end{array}$ & $\underset{44}{18.44^{5}+0 .}$ & $\underset{35}{18.46^{\circ}+0 .}$ & $\begin{array}{c}18.8^{4^{+1}}+0 \\
.19\end{array}$ & 0.226 *** \\
\hline Wing & $7.57 \pm 0.31$ & $7.56 \pm 0.18$ & $7.68 \pm 0.30$ & $7.35 \pm 0.11$ & $7.32 \pm 0.15$ & $7.61 \pm 0.19$ & $0.109 \mathrm{NS}$ \\
\hline Shank & $4.64 \pm 0.19$ & $4.74 \pm 0.25$ & $4.50 \pm 0.10$ & $4.62 \pm 0.11$ & $4.60 \pm 0.24$ & $4.70 \pm 0.19$ & $0.094 \mathrm{NS}$ \\
\hline Liver & $2.37 \pm 0.11$ & $2.41 \pm 0.12$ & $2.35 \pm 0.11$ & $2.39 \pm 0.17$ & $2.38 \pm 0.09$ & $2.40 \pm 0.10$ & $0.059 \mathrm{NS}$ \\
\hline$\underset{\mathrm{dizzar}}{\mathrm{d}}$ & $2.42 \pm 0.12$ & $2.45 \pm 0.18$ & $2.57 \pm 0.14$ & $2.54 \pm 0.24$ & $2.63 \pm 0.34$ & $2.71 \pm 0.26$ & $0.112 \mathrm{NS}$ \\
\hline Heart & $0.50 \pm 0.03$ & $0.53 \pm 0.03$ & $0.49 \pm 0.03$ & $0.52 \pm 0.03$ & $0.52 \pm 0.03$ & $0.50 \pm 0.02$ & $0.015 \mathrm{NS}$ \\
\hline$\underset{\substack{\text { Abdom } \\
\text { inal } \\
\text { fat }}}{\text { fol }}$ & $1.22 \pm 0.18$ & $1.18 \pm 0.20$ & $1.11 \pm 0.11$ & $1.00 \pm 0.10$ & $1.06 \pm 0.12$ & $0.97 \pm 0.09$ & $0.070 \mathrm{NS}$ \\
\hline
\end{tabular}

However, some study revealed significantly $(\mathrm{P}<0.05)$ lower weight of back half, front half, drum \& thigh fed triticale diet when substituted for wheat-based diet ${ }^{[7]}$ which are not supported in the present findings.

\section{CONCLUSION}

Considering the above facts and findings, it may be concluded that triticale based diet at any proportion in broiler ration had no adverse effect on production performance. Growth performance and meat yield of broilers were better with $40 \%$ replacement of maize with triticale in the diet. It is also more profitable due to a reduction of feed cost. So, triticale can easily be used as the replacement of maize in broiler diet on scarcity of maize or its price is higher.

\section{REFERENCES}

1.McNab J (1999). Advances in poultry nutrition in the world. Proceedings of the Seminar and 
International Poultry show. World Poultry Science Association, Bangladesh Branch. 52.

2.Rahman MA and Reza A (1983). Study on the effect of unconventional sources of protein and energy for poultry. M.Sc. Thesis. Dept. of Anim. Nutr., Bangladesh Agricultural University, Mymensingh, Bangladesh.

3.Islam MR, Hossain MD, Bulbul SM and MAR Howlider (1994). Unconventional feeds for broilers. Indian Vet. J. 71:775-780.

4.Boros D (1999). Influence of $\mathrm{R}$ genome on the nutritional value of triticale for broiler chicks. Anim. Feed Sci. Technol. 76: 219-226.

5.Todorov NA (1988). Cereals, pulses and oilseeds; In: De Boer, F. and Bickel. H. (Eds) Livestock Feed Resources and Feed Evaluation in Europe. 47-95.

6.Rao DR, Johnson WM and Sundi GR (1976). Replacement of maize by triticale in broiler diets. British Poultry Science. 17: 269-274.

7.Korver DR, Zuidhof MJ and Lawes KR (2004). Performances characteristics and economic comparision of Broiler chicken fed wheat and triticale based diets. Poultry Science. 83: 716-725.

8.Azmal SA, Bhuiyan AA, Faruque S and Sarker NR (2007). Effect of triticale based diet on the production performance and carcass characteristics of broiler. Journal of the Bangladesh Agricultural University, 5(2):295-301.

9.Sing PK, Khatta VK, Thakur RS, Dey S and Sangwan ML (2003). Effect of phytase supplementation on the performance of broiler chickens fed maize and wheat based diets with different levels of non- phytate phosphorus. AsianAust. J. Anim. Sci. 16(1): 1642-1649.

10.Nesheim MC, Austic RE and Card LE (1979). Poultry Production, $12^{\text {th }}$ edi. 335.

11.Kotula AW, Thomson JE and Kinner JA (1960). Weight increase during chilling of broilers as influenced by methods of opening the abdominal cavity during evisceration. Poult. Sci. 39:26-27.

12.Pandey NK and Shyamsunder G (1990). Carcass Characteristics, meat yield and physicochemical properties of meat from white leghorn cockerels. Indian J. Poult. Sci. 25(4):249-252.

13.Hermes, J. C. and Johnson, R. C. 2004. Effects of feeding various levels of Triticale var. Bogo in the diet of Broiler and Layer chickens. Journal of Applied Poultry Research, 13:667-672.

14.Jones GPD and Taylor RD (2001). The incorporation of whole grain into pelleted broiler chicken diets: production and physiological responses. British poultry science, 42(4): 477-483.
15.Lotfallahian H, Shivazazd $M$ and Nik-khah A (1999). Replacement of corn by triticale in broiler diets. Iranian Journal of Agricultural Sciences. 30: 2, 309-318.

16.Vieira SL, Penz AM, Kessler AM, and Catellan EVJr (1995). A nutritional evaluation of triticale in broiler diets. J. Appl. Poult. Res. 4: 352-355.

17.Belaid A (19940. Nutient and economic value of triticale as feed grain for poultry. CIMMYT Economics working paper no. 94-01. Mexico, D.F.: CIMMYT.

18. Yaqoob MM and Netke SP (1975). Studies on the incorporation of Triricale in diets for growing chicks. British Poultry Science, 16: 45-54.

19. Mahbub ASM, Baqui MA and Sarker NR (2009). Broiler performance with triticale based diet. Sixth International Poultry Show and Seminar, WPSABB, 5-7 March 2009, Dhaka, Bangladesh. 77-81.

20.Charalambous K, Koumas A and Economides S (1986). The effect of triticale grain on the performance of chicks from birth to nine weeks of age. Tech. Bull. Agric. Res. Inst. 79: 1-7.

21.Reddy NV, Rao DR and Sundi GR (1979). Comparison of maize, wheat and triticale in broiler diets. British Poultry Science, 20: 357-362.

22.Smith RL, Jensen LS, Hoveland CS and Hanna WW (1989). Use of pearl millet, sorghum and triticale grain in broiler diets. Journal of Production Agriculture. 2: 78-82.

23.Proudfoot FG and Hulan HW (1988). Nutritive value of triticale as a feed ingredient for broiler chickens. Poultry Science, 67 (12): 1743-1749.

24. Ruiz N, Marion JE, Miles RD and Barnett RB (1987). Nutritive value of new cultivars of triticale and wheat for broiler chick diets. Poultry science, 66(1): 90-97.

25.Angelova L, Marinov B and Surdzhiiska S (1979). Triticale: a new high-protein grain feed crop. Zhivotnov dni Nauki, 16 (1): 85-92.

26.Scholtyssek S and Kutritz B (1986). Improvement of broiler rations with domestic Polish feed components. 3. Triticale in combination with other grains in broiler rations. Archiv gelkunde, 50 (4): 140-143.

27.Shingari BK, Sandha GS, Gill KS and Ichhponani JS (1976) Nutritive value of triticale used as chick feed. Indian Journal of Animal Sciences, 46(6): 299-302.

28.Vohra P, Bersch S, Qual Set CQ and Baker R (1991). Triticale an alternative cereal grain in broiler starter diets. Calif. Agric. 45: 34-37. 
29.Johnson R and Eason P (1988). Evaluation of Triticale for use in diets for meat-type chickens. $J$. Sci. Food Agric. 42: 95-108.

30.Gerry RW (1975). Triticale in broiler rations.

Feed stuffs. 47: 24-25.

31.Abderrezak AJ and Belaid A (1994). Triticale grain for various classes of livestock. Agricultural, Food and Rural Development, Govt. of Alberta, Canada.
32.Islam MR, Mostari MP, Faruque $\mathrm{S}$ and Haque QME (2004). Effect of strain and age at slaughter on the performance and carcass characteristics of cockrels and estimation of carcass characteristics of cockrel from physical characteristics. A Report, Bangladesh Livestock Research Institute, Savar, Dhaka, Bangladesh. 